\title{
Structural Transformations of a Series of Tellurium-Iron Carbonylates and the Isolation of the Cubic Cluster $\left[\mathrm{Te}_{4} \mathrm{Fe}_{4}(\mathrm{CO})_{10}(\mathrm{dppm})\right]$
}

\author{
Kuo-Chih Huang, ${ }^{\dagger}$ Mei-Huey Shieh, ${ }^{\dagger}$ Ren-J ay J ang, ${ }^{\dagger}$ Shie-Ming Peng, ${ }^{\ddagger}$ \\ Gene-Hsiang Lee, ${ }^{\S}$ and Minghuey Shieh*,† \\ Department of Chemistry, National Taiwan Normal University, Taipe 11718, \\ Taiwan, Republic of China, and Department of Chemistry and Instrumentation Center, \\ National Taiwan University, Taipe 10764, Taiwan, Republic of China
}

Received J une 22, 1998

Summary: The cluster growth from the small anionic cluster $\left[\mathrm{TeFe}_{3}(\mathrm{CO})_{9}\right]^{2-}$ to the doublecubic duster $\left[\mathrm{Te}_{10} \mathrm{Fe}_{8}-\right.$ $\left.(\mathrm{CO})_{20}\right]^{2-}$ was systematically established. Further treatment of $\left[\mathrm{Te}_{10} \mathrm{Fe}_{8}(\mathrm{CO})_{20}\right]^{2-}$ with $\left[\mathrm{Cu}_{2}(\mathrm{dppm})_{2}(\mathrm{MeCN})_{4}\right]-$ $\left[\mathrm{BF}_{4}\right]_{2}$ led to the formation of the new dppm-bridged cubic cluster $\left[\mathrm{Te}_{4} \mathrm{Fe}_{4}(\mathrm{CO})_{10}(\mathrm{dppm})\right]$.

\section{Introduction}

Tellurium-rich metal compounds have attracted extensive attention, since tellurides exhibit unusual structural and reactivity patterns and are potentially precursors for new solid-state materials.1,2 Recently, a series of novel tellurium-iron carbonylates have been synthesized and structurally characterized by several different methodologies. These interesting anionic clusters include $\left[\mathrm{TeFe}_{3}(\mathrm{CO})_{12}\right]^{2-}, 3 a\left[\mathrm{TeFe}_{3}(\mathrm{CO})_{9}\right]^{2-}, 3,4\left[\mathrm{Te}_{4} \mathrm{Fe}_{5}-\right.$ $\left.(\mathrm{CO})_{14}\right]^{2-, 5,6}\left[\mathrm{Te}_{6} \mathrm{Fe}_{8}(\mathrm{CO})_{24}\right]^{2-}, 5$ and $\left[\mathrm{Te}_{10} \mathrm{Fe}_{8}(\mathrm{CO})_{20}\right]^{2-} .6$ Nevertheless, their structural relationships and transformations have never been systematically studied. The reaction sequences in which the small molecules transform to larger clusters are of great importance to the extended inorganic solids. ${ }^{7}$ As a consequence, devel op-

* To whom correspondence should be addressed.

† Department of Chemistry, National Taiwan Normal University.

₹ Department of Chemistry, National Taiwan University.

$\S$ Instrumentation Center, National Taiwan University.

(1) (a) Ansari, M. A.; I bers, J . A. Coord. Chem. Rev. 1990, 100, 223. (b) Roof, L. C.; Kolis, J. W. Chem. Rev. 1993, 93, 1037. (c) Kanatzidis, M. G.; Huang, S.-P. Coord. Chem. Rev. 1994, 130, 509.

(2) (a) Bogan, L. E., J r.; Lesch, D. A.; Rauchfuss, T. B. J . Organomet. Chem. 1983, 250, 429. (b) Mathur, P.; Thimmappa, B. H. S.; Rheingold A. L. Inorg. Chem. 1990, 29, 4658 and references therein. (c) Mathur, P.; Reddy, V. D.; Das, K.; Sinha, U. C. J . Organomet. Chem. 1991, 409, 255 and references therein. (d) Roof, L. C.; Pennington, W. T.; Kolis, J . W. J . Am. Chem. Soc. 1990, 112, 8172.

(3) (a) Bachman, R. E.; Whitmire, K. H. Inorg. Chem. 1994, 33, 2527. (b) Roof, L. C.; Smith, D. M.; Drake, G. W.; Pennington, W. T.; Kolis, J. W. Inorg. Chem. 1995, 34, 337.

(4) Shieh, M.; Chen, P.-F.; Tsai, Y.-C.; Shieh, M.-H.; Peng, S.-M.; Lee, G.-H. Inorg. Chem. 1995, 34, 2251.

(5) Shieh, M.; Chen, P.-F.; Peng, S.-M.; Lee, G.-H. Inorg. Chem. 1993, 32, 3389.

(6) Roof, L. C.; Pennington, W. T.; Kolis, J . W. Angew. Chem., Int. Ed. Engl. 1992, 31, 913.

(7) (a) Steigerwald, M. L.; Siegrist, T.; Stuczynski, S. M. Inorg. Chem. 1991, 30, 4940. (b) Steigerwald, M. L.; Siegrist, T.; Gyorgy, E. M.; Hessen, B.; Kwon, Y.-U.; Tanzler, S. M. Inorg. Chem. 1994, 33, 3389. ing and understanding the conversion of small clusters to larger ones is of great interest. In this paper, we demonstrate a facile stepwise cluster growth from $\left[\mathrm{TeFe}_{3}(\mathrm{CO})_{9}\right]^{2-}$ to $\left[\mathrm{Te}_{10} \mathrm{Fe}_{8}(\mathrm{CO})_{20}\right]^{2-}$. The reactions of $\left[\mathrm{Te}_{10} \mathrm{Fe}_{8}(\mathrm{CO})_{20}\right]^{2-}$ with electrophiles are described as well, from which the cubic cluster $\left[\mathrm{Te}_{4} \mathrm{Fe}_{4}(\mathrm{CO})_{10}(\mathrm{dppm})\right]$ is obtained and compared with the double-cubic cluster $\left[\mathrm{Te}_{10} \mathrm{Fe}_{8}(\mathrm{CO})_{20}\right]^{2-}$.

\section{Experimental Section}

All reactions were performed under an atmosphere of pure nitrogen by using standard Schlenk line techniques. ${ }^{8}$ Solvents were purified, dried, and distilled under nitrogen prior to use. $\mathrm{K}_{2} \mathrm{TeO}_{3} \cdot \mathrm{H}_{2} \mathrm{O}$ (Alfa), $\mathrm{TeO}_{2}$ (Strem), $\mathrm{Fe}(\mathrm{CO})_{5}$ (Aldrich), and bis(diphenylphosphino)methane (dppm; Acros) were used as received. Infrared spectra were recorded on a J asco 700 IR or a Perkin-EImer Paragon 500 spectrometer using $\mathrm{CaF}_{2}$ liquid cells. Mass spectra were obtained on a Finnigan TSQ700 mass spectrometer. Elemental analyses were performed on a Perkin-EImer 2400 analyzer at the NSC Regional Instrumental Center at National Taiwan University. ${ }^{1} \mathrm{H}$ NMR spectra were taken on a Varian $200(200 \mathrm{MHz})$ instrument. [TeFe $\left.\left.\mathrm{T}_{3} \mathrm{CO}\right)_{9}\right]^{2-}, 3,4$ $\mathrm{Te}_{2} \mathrm{Fe}_{3}(\mathrm{CO})_{9},{ }^{9}$ and $\left[\mathrm{Cu}_{2}(\mathrm{dppm})_{2}(\mathrm{MeCN})_{4}\right]\left[\mathrm{BF}_{4}\right]_{2}{ }^{10}$ were prepared by the published methods.

Formation of $\left[\mathrm{Et}_{4} \mathrm{~N}_{2}\left[\mathrm{Te}_{4} \mathrm{Fe}_{5}(\mathrm{CO})_{14}\right]\right.$. To a mixture of $0.239 \mathrm{~g}(0.296 \mathrm{mmol})$ of $\left[\mathrm{Et}_{4} \mathrm{~N}\right]_{2}\left[\mathrm{TeFe}_{3}(\mathrm{CO})_{9}\right]$ and $0.100 \mathrm{~g}(0.148$ $\mathrm{mmol}$ ) of $\mathrm{Te}_{2} \mathrm{Fe}_{3}(\mathrm{CO})_{9}$ was added $20 \mathrm{~mL}$ of THF. After being stirred for 3 days at room temperature, the solution was filtered and solvent was removed under vacuum. The residue was washed with hexanes and ether and then extracted with $\mathrm{CH}_{2} \mathrm{Cl}_{2}$ to give $0.110 \mathrm{~g}(0.076 \mathrm{mmol})$ of $\left[\mathrm{Et}_{4} \mathrm{~N}\right]_{2}\left[\mathrm{Te}_{4} \mathrm{Fe}_{5}(\mathrm{CO})_{14}\right]$ $\left(26 \%\right.$ based on $\left.\left[\mathrm{Et}_{4} \mathrm{~N}\right]_{2}\left[\mathrm{TeFe}_{3}(\mathrm{CO})_{9}\right]\right)$. IR $\left(v_{\mathrm{CO}}, \mathrm{MeCN}\right)$ for $\left[\mathrm{Et}_{4} \mathrm{~N}_{2}\left[\mathrm{Te}_{4} \mathrm{Fe}_{5}(\mathrm{CO})_{14}\right]: 2025 \mathrm{w}, 2008 \mathrm{~s}, 1975 \mathrm{vs}, 1940 \mathrm{~m} \mathrm{~cm}^{-1}\right.$.

Formation of $\left[\mathrm{Et}_{4} \mathrm{~N}\right]_{2}\left[\mathrm{Te}_{6} \mathrm{Fe}_{8}(\mathrm{CO})_{24}\right]$. To a mixture of $0.100 \mathrm{~g}(0.069 \mathrm{mmol})$ of $\left[\mathrm{Et}_{4} \mathrm{~N}\right]_{2}\left[\mathrm{Te}_{4} \mathrm{Fe}_{5}(\mathrm{CO})_{14}\right]$ and $0.086 \mathrm{~g}$ $(0.127 \mathrm{mmol})$ of $\mathrm{Te}_{2} \mathrm{Fe}_{3}(\mathrm{CO})_{9}$ was added $40 \mathrm{~mL}$ of $\mathrm{CH}_{2} \mathrm{Cl}_{2}$. The solution turned reddish brown immediately and was filtered, and solvent was removed under vacuum. The residue was washed with hexanes and ether and then extracted with $\mathrm{CH}_{2} \mathrm{Cl}_{2}$ to give $0.110 \mathrm{~g}(0.051 \mathrm{mmol})$ of $\left[\mathrm{Et}_{4} \mathrm{~N}_{2}\left[\mathrm{Te}_{6} \mathrm{Fe}_{8}(\mathrm{CO})_{24}\right]\right.$

(8) Shriver, D. F.; Drezdzon, M. A. The Manipulation of Air Sensitive Compounds; Wiley: New York, 1986.

(9) Lesch, D. A.; Rauchfuss, T. B. Inorg. Chem. 1981, 20, 3583.

(10) Díez, J .; Gamasa, P.; Gimeno, J .; Tiripicchio, A.; Camellini, M. T. J . Chem. Soc., Dalton Trans. 1987, 1275. 
(74\% based on $\left[\mathrm{Et}_{4} \mathrm{~N}_{2}\left[\mathrm{Te}_{4} \mathrm{Fe}_{5}(\mathrm{CO})_{14}\right]\right)$. IR $\left(v_{\mathrm{CO}}, \mathrm{CH}_{2} \mathrm{Cl}_{2}\right)$ for $\left[\mathrm{Et}_{4} \mathrm{~N}\right]_{2}\left[\mathrm{Te}_{6} \mathrm{Fe}_{8}(\mathrm{CO})_{24}\right]: 2026 \mathrm{~s}, 2004 \mathrm{vs}, 1956 \mathrm{~m}(\mathrm{br}) \mathrm{cm}^{-1}$.

Formation of [TMBA $]_{2}\left[\mathrm{Te}_{10} \mathrm{Fe}_{8}(\mathrm{CO})_{20}\right]$. To a mixture of $3.20 \mathrm{~g}(1.46 \mathrm{mmol})$ of $\left[\mathrm{TMBA}_{2}\left[\mathrm{Te}_{6} \mathrm{Fe}_{8}(\mathrm{CO})_{24}\right]\right.$ and $0.967 \mathrm{~g}$ (7.58 $\mathrm{mmol}$ ) of Te powder was added $40 \mathrm{~mL}$ of THF. After being stirred and heated at $50{ }^{\circ} \mathrm{C}$ for 3 days, the solution was filtered and solvent was removed under vacuum. The residue was washed with hexanes and ether and then extracted with $\mathrm{CH}_{2} \mathrm{Cl}_{2}$ to give $2.24 \mathrm{~g}(0.867 \mathrm{mmol})$ of [TMBA $]_{2}\left[\mathrm{Te}_{10} \mathrm{Fe}_{8}(\mathrm{CO})_{20}\right]$ (60\% based on [TMBA $\left.]_{2}\left[\mathrm{Te}_{6} \mathrm{Fe}_{8}(\mathrm{CO})_{24}\right]\right)$. IR $\left(v_{\mathrm{CO}}, \mathrm{CH}_{2} \mathrm{Cl}_{2}\right): 2026$ S, 2015 sh, 1979 s, $1924 \mathrm{w} \mathrm{cm}^{-1}$. Anal. Calcd (found) for [TMBA $]_{2}\left[\mathrm{Te}_{10} \mathrm{Fe}_{8}(\mathrm{CO})_{20}\right]: \mathrm{C}, 18.57$ (18.59); $\mathrm{H}, 1.24$ (1.44); N, 1.08 (0.95).

Reaction of [TMBA $]_{2}\left[\mathrm{Te}_{10} \mathrm{Fe}_{8}(\mathrm{CO})_{20}\right]$ with $\mathrm{Na} / \mathrm{Naph}$ thalene. To a sample of $0.297 \mathrm{~g}(0.115 \mathrm{mmol})$ of $[\mathrm{TMBA}]_{2}\left[\mathrm{Te}_{10^{-}}\right.$ $\mathrm{Fe}_{8}(\mathrm{CO})_{20}$ ] in $15 \mathrm{~mL}$ of $\mathrm{THF}$ was added $1.2 \mathrm{~mL}$ of a solution which was prepared from $0.349 \mathrm{~g}(0.015 \mathrm{~mol})$ of $\mathrm{Na}$ and 1.94 $\mathrm{g}(0.015 \mathrm{~mol})$ of naphthalene in $40 \mathrm{~mL}$ of THF. The mixed solution was stirred for $10 \mathrm{~h}$ and filtered, and solvent was removed under vacuum. The residue was washed with hexanes and then extracted with $\mathrm{CH}_{2} \mathrm{Cl}_{2}$ to give $0.11 \mathrm{~g}(0.050$ $\mathrm{mmol})$ of $[\mathrm{TMBA}]_{2}\left[\mathrm{Te}_{6} \mathrm{Fe}_{8}(\mathrm{CO})_{24}\right](43 \% \text { based on [TMBA }]_{2}\left[\mathrm{Te}_{10^{-}}\right.$ $\left.\left.\mathrm{Fe}_{8}(\mathrm{CO})_{20}\right]\right)$. IR $\left(v_{\mathrm{CO}}, \mathrm{CH}_{2} \mathrm{Cl}_{2}\right)$ for $[\mathrm{TMBA}]_{2}\left[\mathrm{Te}_{6} \mathrm{Fe}_{8}(\mathrm{CO})_{24}\right]: 2027$ m, 2006 vs, $1959 \mathrm{~m}, \mathrm{br} \mathrm{cm}^{-1}$.

Reaction of [TMBA] $]_{2}\left[\mathrm{Te}_{10} \mathrm{Fe}_{8}(\mathrm{CO})_{20}\right]$ with $\mathrm{MeSO}_{3} \mathrm{CF}_{3}$. To a sample of $0.203 \mathrm{~g}(0.079 \mathrm{mmol})$ of $[\mathrm{TMBA}]_{2}\left[\mathrm{Te}_{10} \mathrm{Fe}_{8}(\mathrm{CO})_{20}\right]$ in $10 \mathrm{~mL}$ of THF was added $0.04 \mathrm{~mL}(0.35 \mathrm{mmol})$ of $\mathrm{MeSO}_{3^{-}}$ $\mathrm{CF}_{3}$. The mixed solution was stirred for $3 \mathrm{~h}$ and filtered, and solvent was removed under vacuum. The residue was extracted with hexanes to give the known butterfly complex 0.02 $\mathrm{g}(0.034 \mathrm{mmol})\left(\mathrm{Fe}_{2}(\mathrm{CO})_{6}(\mu \text {-TeMe })_{2},{ }^{11}\right.$ which was identified by IR and mass spectroscopy.

Formation of $\left[\mathrm{Te}_{4} \mathrm{Fe}_{4}(\mathrm{CO})_{10}(\mathrm{dppm})\right]$. To a mixture of $0.774 \mathrm{~g}(0.300 \mathrm{mmol})$ of $[\mathrm{TMBA}]_{2}\left[\mathrm{Te}_{10} \mathrm{Fe} \mathrm{e}_{8}(\mathrm{CO})_{20}\right]$ and $0.369 \mathrm{~g}$ $(0.300 \mathrm{mmol})$ of $\left[\mathrm{Cu}_{2}(\mathrm{dppm})_{2}(\mathrm{MeCN})_{4}\right]\left[\mathrm{BF}_{4}\right]_{2}$ was added $30 \mathrm{~mL}$ of THF. After being stirred and heated at $50^{\circ} \mathrm{C}$ for $40 \mathrm{~h}$, the solution was filtered and solvent was removed under vacuum. The residue was washed with $\mathrm{MeOH}$ and ether and then extracted with THF to give $0.25 \mathrm{~g}(0.169 \mathrm{mmol})$ of [ $\mathrm{Te}_{4}$ $\left.\mathrm{Fe}_{4}(\mathrm{CO})_{10}(\mathrm{dppm})\right](28 \%)$. IR $\left(v_{\mathrm{CO}}, \mathrm{CH}_{2} \mathrm{Cl}_{2}\right)$ for $\left[\mathrm{Te}_{4} \mathrm{Fe}_{4}(\mathrm{CO})_{10^{-}}\right.$ (dppm)]: 2053 s, 2032 vs, 1994 vs, $1940 \mathrm{w} \mathrm{cm}^{-1}$. Anal. Calcd (found) for $\left[\mathrm{Te}_{4} \mathrm{Fe}_{4}(\mathrm{CO})_{10}(\mathrm{dppm})\right]$ : C, 29.19 (29.10); H, 1.63 (1.81). ${ }^{1} \mathrm{H} \mathrm{NMR}\left(\mathrm{CDCl}_{3}, 298 \mathrm{~K}\right): \delta 7.55-7.22(\mathrm{~m}, 2 \mathrm{OH}), \delta 4.04$ $\left(\mathrm{t}, 2 \mathrm{H}, \mathrm{J} \mathrm{P}-\mathrm{H}=10 \mathrm{~Hz}\right.$ ). Mp: $319-320^{\circ} \mathrm{C}$ dec. This complex is soluble in ether, $\mathrm{CH}_{2} \mathrm{Cl}_{2}$, and THF.

$X$-ray Structural Characterization of $\left[\mathrm{Te}_{4} \mathrm{Fe}_{4}(\mathrm{CO})_{10^{-}}\right.$ (dppm)] $\cdot \mathbf{C H}_{2} \mathbf{C l}_{\mathbf{2}}$ (1). A summary of selected crystallographic data for $\left[\mathrm{Te}_{4} \mathrm{Fe}_{4}(\mathrm{CO})_{10}(\mathrm{dppm})\right] \cdot \mathrm{CH}_{2} \mathrm{Cl}_{2}(\mathbf{1})$ is given in Table 1 . Data collection was carried out on a Nonius CAD-4 diffractometer using graphite-monochromated Mo K $\alpha$ radiation at $25^{\circ} \mathrm{C}$ employing the $\theta / 2 \theta$ scan mode. A $\psi$-scan absorption correction was made. ${ }^{12}$ The crystal was mounted on glass fibers with epoxy cement. Data reduction and structural refinement were performed using the NRCC-SDP-VAX packages, ${ }^{13}$ and atomic scattering factors were taken from ref 14.

Reddish black crystals of $\mathbf{1}$ suitable for X-ray analysis were grown from hexane/ $\mathrm{CH}_{2} \mathrm{Cl}_{2}$ solutions. A total of 7842 unique reflections were collected and corrected for absorption and decay. The structure was solved by the heavy-atom method and refined by least-squares cycles. All non-hydrogen atoms were refined with anisotropic thermal parameters. Fullmatrix least-squares refinement of $\mathbf{1}$ led to convergence with $\mathrm{R}=3.4 \%$ and $\mathrm{R}_{\mathrm{w}}=3.2 \%$ for those reflections with $\mathrm{I}>2.0$ $\sigma(\mathrm{I})$.

(11) Bachman, R. E.; Whitmire, K. H. Organometallics 1993, 12 1988.

(12) North, A. C. T.; Philips, D. C.; Mathews, F. S. Acta Crystallogr. 1968, A24, 351

(13) Gabe, E. J .; Le Page, Y.; Charland, J . P.; Lee, F. L.; White, P. S. J . Appl. Crystallogr. 1989, 22, 384.

(14) International Tables for X-ray Crystallography; Kynoch Press: Birmingham, England, 1974; Vol. IV.
Table 1. Selected Crystallographic Data' for $\left[\mathrm{Te}_{4} \mathrm{Fe}_{4}(\mathrm{CO})_{10}(\mathrm{dppm})\right] \cdot \mathrm{CH}_{2} \mathrm{Cl}_{2}$ (1)

$\begin{array}{ll}\text { empirical formula } & \mathrm{C}_{36} \mathrm{H}_{24} \mathrm{Cl}_{2} \mathrm{Fe}_{4} \mathrm{O}_{10} \mathrm{P}_{2} \mathrm{Te}_{4} \\ \text { fw } & 1483.21 \\ \text { cryst syst } & \text { triclinic } \\ \text { space group } & \mathrm{P} \overline{1} \\ \mathrm{a}, \AA & 11.724(5) \\ \mathrm{b}, \AA & 13.836(5) \\ \mathrm{C}, \AA & 15.116(5) \\ \alpha, \text { deg } & 84.97(3) \\ \beta, \text { deg } & 86.70(3) \\ \gamma, \text { deg } & 66.24(3) \\ \mathrm{V}, \AA^{3} & 2235(2) \\ \mathrm{D}\left(\text { calcd), } \mathrm{Mg} \mathrm{m}^{-3}\right. & 2.204 \\ \text { abs coeff, } \mathrm{cm}^{-1} & 40.837 \\ \mathrm{~T}_{\min } / \mathrm{T}_{\max } & 0.90 / 1.00 \\ \text { residuals: } \mathrm{R} ; \mathrm{R}_{\mathrm{w}}{ }^{\mathrm{b}} & 0.034 ; 0.032\end{array}$

a All data were obtained from a Nonius (CAD-4) diffractometer with Mo K $\alpha$ radiation $\left(\lambda=0.7107 \AA\right.$ ) at $25{ }^{\circ} \mathrm{C}$. ${ }^{\mathrm{b}}$ The functions minimized during least-squares cycles were $R=\sum\left|F_{o}-F_{c}\right| / \sum F_{o}$ and $R_{w}=\left[\sum w\left(F_{0}-F_{c}\right)^{2} / \Sigma w\left(F_{0}\right)^{2}\right]^{1 / 2}$.

Table 2. Selected Bond Distances $(\AA \AA)$ and Bond Angles (deg) for $\left[\mathrm{Te}_{4} \mathrm{Fe}_{4}(\mathrm{CO})_{10}(\mathrm{dppm})\right] \cdot \mathrm{CH}_{2} \mathrm{Cl}_{2}$ (1)

\begin{tabular}{llll} 
& \multicolumn{4}{c}{ (A) Distances } & \\
$\mathrm{Te}(1)-\mathrm{Fe}(1)$ & $2.615(2)$ & $\mathrm{Te}(1)-\mathrm{Fe}(2)$ & $2.607(2)$ \\
$\mathrm{Te}(1)-\mathrm{Fe}(3)$ & $2.619(2)$ & $\mathrm{Te}(2)-\mathrm{Fe}(1)$ & $2.620(2)$ \\
$\mathrm{Te}(2)-\mathrm{Fe}(2)$ & $2.623(2)$ & $\mathrm{Te}(2)-\mathrm{Fe}(4)$ & $2.608(2)$ \\
$\mathrm{Te}(3)-\mathrm{Fe}(1)$ & $2.605(2)$ & $\mathrm{Te}(3)-\mathrm{Fe}(3)$ & $2.619(2)$ \\
$\mathrm{Te}(4)-\mathrm{Fe}(2)$ & $2.621(2)$ & $\mathrm{Te}(4)-\mathrm{Fe}(3)$ & $2.621(2)$ \\
$\mathrm{Te}(4)-\mathrm{Fe}(4)$ & $2.613(2)$ & $\mathrm{Te}(3)-\mathrm{Fe}(4)$ & $2.625(2)$
\end{tabular}

$\mathrm{Fe}(1)-\mathrm{Te}(1)-\mathrm{Fe}(2)$

(B) Bond Angles

$\mathrm{Fe}(2)-\mathrm{Te}(1)-\mathrm{Fe}(3)$

$\mathrm{Fe}(1)-\mathrm{Te}(2)-\mathrm{Fe}(4)$

$\mathrm{Fe}(1)-\mathrm{Te}(3)-\mathrm{Fe}(3)$

$\mathrm{Fe}(3)-\mathrm{Te}(3)-\mathrm{Fe}(4)$

$\mathrm{Fe}(2)-\mathrm{Te}(4)-\mathrm{Fe}(4)$

$\mathrm{Te}(1)-\mathrm{Fe}(1)-\mathrm{Te}(2)$

\subsection{5(6) $\mathrm{Fe}(1)-\mathrm{Te}(1)-\mathrm{Fe}(3)$}

97.40(5) $\mathrm{Fe}(1)-\mathrm{Te}(2)-\mathrm{Fe}(2)$

96.66(5) Fe(2)-Te(2)-Fe(4)

98.14(6) $\mathrm{Fe}(1)-\mathrm{Te}(3)-\mathrm{Fe}(4)$

95.51(6) $\mathrm{Fe}(2)-\mathrm{Te}(4)-\mathrm{Fe}(3)$

98.55(6) $\mathrm{Fe}(3)-\mathrm{Te}(4)-\mathrm{Fe}(4)$

86.23(5) Te(1)-Fe(1)-Te(3)

$97.88(6)$

$92.47(6)$

$98.64(6)$

96.60(5)

96.99(5)

95.71(6)

82.04(5)

Selected bond distances and angles of $\mathbf{1}$ are listed in Table 2. Additional crystallographic data are available as Supporting I nformation.

\section{Results and Discussion}

The previous study ${ }^{3,4}$ showed that the reaction of $\mathrm{K}_{2} \mathrm{TeO}_{3}$ with 3 equiv of $\mathrm{Fe}(\mathrm{CO})_{5} / \mathrm{KOH}$ in $\mathrm{MeOH}$ led to the formation of the open cluster $\left[\mathrm{TeFe}_{3}(\mathrm{CO})_{12}\right]^{2-}$, which then decarbonylated to generate the tetrahedral complex $\left[\mathrm{TeFe}_{3}(\mathrm{CO})_{9}\right]^{2-}$. However, when $\mathrm{K}_{2} \mathrm{TeO}_{3}$ reacted with 1 equiv of $\mathrm{Fe}(\mathrm{CO})_{5} / \mathrm{KOH}$ in $\mathrm{MeOH}$, the large cluster anion $\left[\mathrm{Te}_{6} \mathrm{Fe}_{8}(\mathrm{CO})_{24}\right]^{2-}$ was formed. ${ }^{4}$ These results indicated that the $\mathrm{Te}-\mathrm{Fe}-\mathrm{CO}$ system is very versatile, and different stoichiometries and subtle changes of the reaction conditions could give rise to different outcomes. These prompted us to explore the cluster transformations and to attempt to elucidate the cluster growth processes in this system.

Cluster Growth Processes. The cluster growth processes are summarized in Scheme 1. When the tetrahedral cluster $\left[\mathrm{TeF}_{3}(\mathrm{CO})_{9}\right]^{2-}$ was treated with $\mathrm{Te}_{2}-$ $\mathrm{Fe}_{3}(\mathrm{CO})_{9}$, the mediun-sized cluster $\left[\mathrm{Te}_{4} \mathrm{Fe}_{5}(\mathrm{CO})_{14}\right]^{2-}$ was obtained. One can envision $\left[\mathrm{Te}_{4} \mathrm{Fe}_{5}(\mathrm{CO})_{14}\right]^{2-}$ to be composed of the anion $\left[\mathrm{Te}_{2} \mathrm{Fe}_{2}(\mathrm{CO})_{6}\right]^{2-}$ and one $\mathrm{Te}_{2} \mathrm{Fe}_{3-}$ $(\mathrm{CO})_{9}$ with the loss of one $\mathrm{CO}$, which seems to have no direct relevance to $\left[\mathrm{TeFe}_{3}(\mathrm{CO})_{9}\right]^{2-}$ and $\mathrm{Te}_{2} \mathrm{Fe}_{3}(\mathrm{CO})_{9}$. Therefore, the formation of $\left[\mathrm{Te}_{4} \mathrm{Fe}_{5}(\mathrm{CO})_{14}\right]^{2-}$ can be regarded as resulting from complicated bond breakage and rearrangement processes. It was more interesting 


\section{Scheme 1}

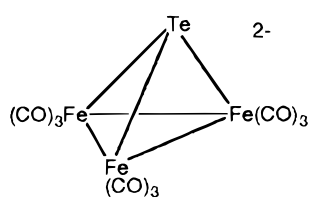

$\mathrm{Te}_{2} \mathrm{Fe}_{3}(\mathrm{CO})_{9}$

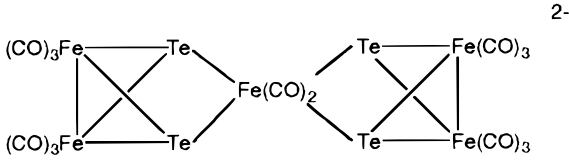

$$
\downarrow \mathrm{Te}_{2} \mathrm{Fe}_{3}(\mathrm{CO})_{9}
$$
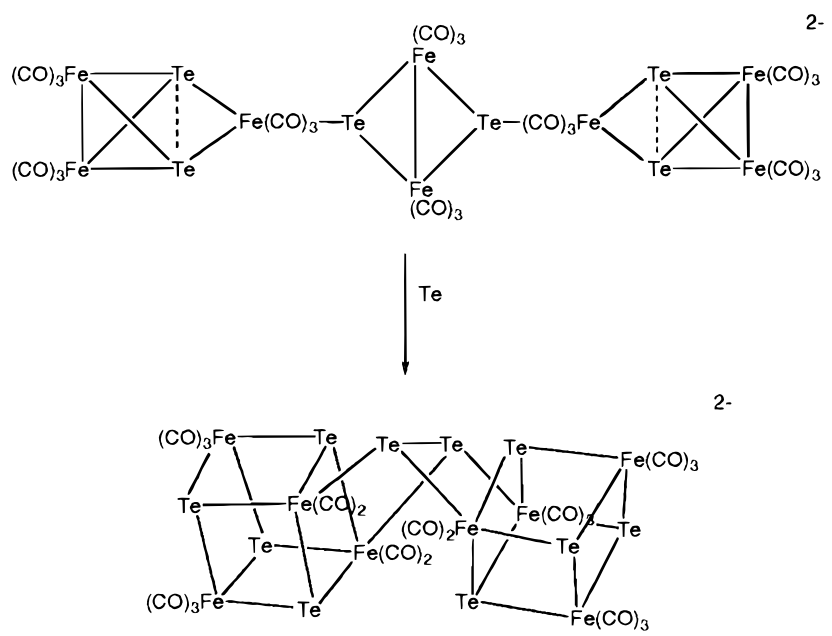

to note that when $\left[\mathrm{Te}_{4} \mathrm{Fe}_{5}(\mathrm{CO})_{14}\right]^{2-}$ further reacted with $\mathrm{Te}_{2} \mathrm{Fe}_{3}(\mathrm{CO})_{9}$, the large cluster $\left[\mathrm{Te}_{6} \mathrm{Fe}_{8}(\mathrm{CO})_{24}\right]^{2-}$ was cleanly yielded. This cluster growth process is quite reasonable, because $\left[\mathrm{Te}_{6} \mathrm{Fe}_{8}(\mathrm{CO})_{24}\right]^{2-}$ can be approximately viewed as one $\left[\mathrm{Te}_{4} \mathrm{Fe}_{5}(\mathrm{CO})_{14}\right]^{2-}$ anion and one $\mathrm{Te}_{2} \mathrm{Fe}_{3}(\mathrm{CO})_{9}$.

Utilizing this methodology, we wondered whether the larger cluster can be obtained when $\left[\mathrm{Te}_{6} \mathrm{Fe}_{8}(\mathrm{CO})_{24}\right]^{2-}$ was treated with $\mathrm{Te}_{2} \mathrm{Fe}_{3}(\mathrm{CO})_{9}$ or Te or other Fe sources. This is indeed the case. When $\left[\mathrm{Te}_{6} \mathrm{Fe}_{8}(\mathrm{CO})_{24}\right]^{2-}$ was treated with 4 equiv of $\mathrm{Te}$, the double-cubic cluster $\left[\mathrm{Te}_{10} \mathrm{Fe}_{8}(\mathrm{CO})_{20}\right]^{2-}$ was obtained in good yield. The double-cubic cluster was previously reported to be generated from the reaction of $\mathrm{Fe}(\mathrm{CO})_{5}$ with "Zintl" ion $\mathrm{Te}_{4}{ }^{2-}$ and excess Te. The route we describe here from $\left[\mathrm{Te}_{6} \mathrm{Fe}_{8}(\mathrm{CO})_{24}\right]^{2-}$ to $\left[\mathrm{Te}_{10} \mathrm{Fe}_{8}(\mathrm{CO})_{20}\right]^{2-}$ is convenient and high yielding. From a structural viewpoint, there is no obvious relationship between these two clusters; however, the structural transformation is possible by adjustment of the appropriate stoichi ometry.

In this study, the facile processes of the cluster growth from the small $\left[\mathrm{TeFe}_{3}(\mathrm{CO})_{9}\right]^{2-}$ to the large $\left[\mathrm{Te}_{10} \mathrm{Fe}_{8-}\right.$ $\left.(\mathrm{CO})_{20}\right]^{2-}$ are established. Other types of cluster expansion processes have been seen in our previous studies of Se-Fe and $\mathrm{E}-\mathrm{Mn}\left(\mathrm{E}=\mathrm{S}\right.$, Se) systems. ${ }^{15,16}$ In this case, larger cluster skel etons are observed probably due to the greater size of the Te atom. The results all

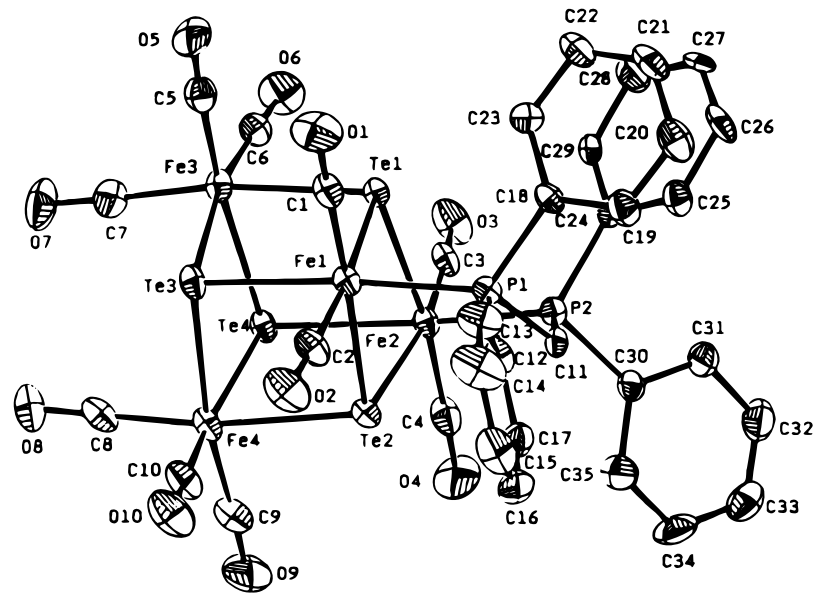

Figure 1. ORTEP diagram showing the structure and atom labeling for $\mathbf{1}$.

indicate that the cluster formation is gradual and may be predictable and also provide some useful information on further cluster expansion reactions.

Reactivity of $\left[\mathrm{Te}_{10} \mathrm{Fe}_{8}(\mathrm{CO})_{20}\right]^{2-}$. Since the double cubic cluster $\left[\mathrm{Te}_{10} \mathrm{Fe}_{8}(\mathrm{CO})_{20}\right]^{2-}$ is structurally interesting and can be obtained easily from $\left[\mathrm{Te}_{6} \mathrm{Fe}_{8}(\mathrm{CO})_{24}\right]^{2-}$, further reactivity studies of $\left[\mathrm{Te}_{10} \mathrm{Fe}_{8}(\mathrm{CO})_{20}\right]^{2-}$ were therefore carried out. It was found that $\left[\mathrm{Te}_{10} \mathrm{~F} \mathrm{e}_{8}(\mathrm{CO})_{20}\right]^{2-}$ can be reconverted to $\left[\mathrm{Te}_{6} \mathrm{Fe}_{8}(\mathrm{CO})_{24}\right]^{2-}$ upon reduction with $\mathrm{Na}$ /naphthalene (eq 1 ). To test the basic sites of

$$
\left[\mathrm{Te}_{6} \mathrm{Fe}_{8}(\mathrm{CO})_{24}\right]^{2-} \underset{\mathrm{Na} / \text { naphthalene }}{\stackrel{4 T e}{\longrightarrow}}\left[\mathrm{Te}_{10} \mathrm{Fe}_{8}(\mathrm{CO})_{20}\right]^{2-}
$$

$\left[\mathrm{Te}_{6} \mathrm{Fe}_{8}(\mathrm{CO})_{24}\right]^{2-}$, we treated $\left[\mathrm{Te}_{10} \mathrm{Fe}_{8}(\mathrm{CO})_{20}\right]^{2-}$ with the methylation agent $\mathrm{MeSO}_{3} \mathrm{CF}_{3}$. However, the reaction proceeded with severe bond breakage and formation to give the known butterfly complex ${ }^{11} \mathrm{Fe}_{2}(\mathrm{CO})_{6}(\mu-\mathrm{TeMe})_{2}$. When $\left[\mathrm{Te}_{10} \mathrm{Fe}_{8}(\mathrm{CO})_{20}\right]^{2-}$ was treated with $\left[\mathrm{Cu}_{2}(\mathrm{dppm})_{2-}\right.$ $\left.(\mathrm{MeCN})_{4}\right]\left[\mathrm{BF}_{4}\right]_{2}$, the dppm-bridged cubic cluster [Te $\left.{ }_{4} \mathrm{Fe}_{4}(\mathrm{CO})_{10}(\mathrm{dppm})\right]$ (1) was obtained (eq 2). Cluster $\mathbf{1}$

$$
\begin{array}{r}
{\left[\mathrm{Te}_{10} \mathrm{Fe}_{8}(\mathrm{CO})_{20}\right]^{2-}+\left[\mathrm{Cu}_{2}(\mathrm{dppm})_{2}(\mathrm{MeCN})_{4}\right]\left[\mathrm{BF}_{4}\right]_{2} \rightarrow} \\
{\left[\mathrm{Te}_{4} \mathrm{Fe}_{4}(\mathrm{CO})_{10}(\mathrm{dppm})\right]}
\end{array}
$$

can be considered to result from the oxidative fragmentation of $\left[\mathrm{Te}_{10} \mathrm{Fe}_{8}(\mathrm{CO})_{20}\right]^{2-}$ by the $\mathrm{Cu}(\mathrm{I})$ complex followed by the chelation of the dppm ligand. Direct reaction of $\left[\mathrm{Te}_{10} \mathrm{Fe}_{8}(\mathrm{CO})_{20}\right]^{2-}$ with dppm failed to produce cluster 1.

The reactivity investigation showed that the double cubic cluster tended to undergo fragmentation to give the cubic or even smaller fragments depending upon the incoming reagents. However, the potential of $\left[\mathrm{Te}_{10} \mathrm{~F} \mathrm{e}_{8-}\right.$ $\left.(\mathrm{CO})_{20}\right]^{2-}$ to serve as a cubic precursor is promising, and further study of its cluster expansion is now in progress.

Structure of $\left[\mathrm{Te}_{4} \mathrm{Fe}_{4}(\mathrm{CO})_{10}(\mathrm{dppm})\right] \cdot \mathrm{CH}_{2} \mathrm{Cl}_{2}$ (1). $\left[\mathrm{Te}_{4} \mathrm{Fe}_{4}(\mathrm{CO})_{10}(\mathrm{dppm})\right]$ was structurally characterized by single-crystal X-ray diffraction. As shown in Figure 1,

(15) Shieh, M.; Shieh, M.-H.; Tsai, Y.-C.; Ueng, C.-H. Inorg. Chem 1995, 34, 5088

(16) Huang, K.-C.; Tsai, Y.-C.; Lee, G.-H.; Peng, S.-M.; Shieh, M. Inorg. Chem. 1997, 36, 4421. 
the $\mathrm{Te}_{4} \mathrm{Fe}_{4}$ core exhibits a cubic geometry with the dppm ligand bridging across two $\mathrm{Fe}$ atoms. Each iron atom in $\mathbf{1}$ is octahedrally coordinated and obeys the 18el ectron count. The Te-Fe distance averages $2.616 \AA$ and is close to those of the structurally related doublecubic cluster $\left[\mathrm{Te}_{10} \mathrm{Fe}_{8}(\mathrm{CO})_{20}\right]^{2-}(2.62 \AA)$ and the cubic clusters $\left[\mathrm{Te}_{4} \mathrm{Fe}_{4}(\mathrm{SPh})_{4}\right]^{3-}(2.63 \AA),{ }_{1}^{17}\left[\mathrm{Te}_{4} \mathrm{Fe}_{4}(\mathrm{TePh})_{4}\right]^{3-}$ $(2.622 \AA),{ }^{18}$ and $\left[\mathrm{Te}_{4} \mathrm{Fe}_{4}(\mathrm{SiPr})_{4}\right]^{3-}(2.627 \AA) .{ }^{19}$ In $\mathbf{1}$, the internal angles in the $\mathrm{Te}_{4} \mathrm{Fe}_{4}$ cube are between 82.04 and $98.64^{\circ}$, close to $90^{\circ}$, indicative of a slight distortion

(17) Barbaro, P.; Bencini, A.; Bertini, I.; Briganti, F.; Midollini, S. J. Am. Chem. Soc. 1990, 112, 7238.

(18) Simon, W.; Wilk, A.; Krebs, B.; Henkel, G. Angew. Chem., Int. Ed. Engl. 1987, 26, 1009.

(19) Stephan, H.-O.; Chen, C.; Henkel, G.; Griesar, K.; Haase, W. J. Chem. Soc., Chem. Commun. 1993, 886. from the ideal cube. This is different from the previously characterized cubes $\left[\mathrm{Te}_{4} \mathrm{Fe}_{4}(\mathrm{EPh})_{4}\right]^{3-}(\mathrm{E}=\mathrm{S}$, $\mathrm{Te}),{ }^{17,18}$ which contain angles deviating greatly from $90^{\circ}$, probably due to the bridging effect of the dppm ligand on the cubic structure.

Acknowledgment. We thank the National Science Council of the Republic of China for financial support (Grant No. NSC-87-2113-M-003-001).

Supporting Information Available: Complete listings of crystallographic data, atomic positional parameters, bond distances and angles, and anisotropic thermal parameters of cluster 1 (7 pages). Ordering information is given on any current masthead page.

OM980516F 